\title{
Empoasca papayae (Hemiptera: Cicadellidae)-Mediated Transmission of Papaya Meleira Virus-Mexican Variant in Mexico
}

\author{
Isabel García-Cámara, ${ }^{1}$ Raúl Tapia-Tussell, ${ }^{2}$ Anuar Magaña-Álvarez, ${ }^{1}$ Alberto Cortés Velázquez, ${ }^{1}$ Rodolfo Martín-Mex, \\ Oscar Moreno-Valenzuela, ${ }^{3}$ and Daisy Pérez-Brito ${ }^{1, \dagger}$ \\ ${ }^{1}$ Laboratorio GeMBio, Centro de Investigación Científica de Yucatán A.C., Mérida, Yucatán 97205, México \\ ${ }^{2}$ Unidad de Energía Renovable, Centro de Investigación Científica de Yucatán AC, Sierra Papacal, CP 97302, Mérida, Yucatán, \\ México \\ ${ }^{3}$ Unidad de Bioquímica y Biología Molecular de Plantas, Centro de Investigación Científica de Yucatán A.C., Mérida, Yucatán \\ 97205, México
}

\begin{abstract}
Papaya meleira virus $(\mathrm{PMeV})$ causes sticky disease in Carica papaya in Brazil and Mexico. Despite its economic importance and the need for effective phytosanitary control, it remains unknown whether any insect is the vector of this virus. The aim of this work was to identify potential insect vectors of the PMeV-Mexican variant (PMeV-Mx) and determine whether these potential vectors are capable of transmitting the virus. Adult insects were collected in papaya fields in the south-southeast region of Mexico and were identified morphologically and molecularly. Their abundance and frequency were determined, and quantitative reverse transcription polymerase chain reaction was performed to establish

assays were conducted under controlled conditions using E. papayae on C. papaya 'Maradol'. E. papayae was a carrier of PMeV-Mx at $6 \mathrm{~h}$ after exposure, and its viral titer increased with time, peaking at 2.125 $\mathrm{pg} / \mu \mathrm{l}$ of PMeV-Mx RNA from $20 \mathrm{ng} / \mu \mathrm{l}$ of cDNA, 5 days after exposure (dae). From 14 days after plants were exposed to insects, PMeV-Mx was detected and quantified in $100 \%$ of the evaluated papaya plants, whose viral RNA titer increased from 0.06 (21 dae) to $26.6 \mathrm{pg} / \mu \mathrm{l}$ of $\mathrm{PMeV}$ Mx RNA (60 dae) from $20 \mathrm{ng} / \mu 1$ of cDNA. Three months later, these plants developed sticky disease symptoms, demonstrating that $E$. papayae is capable of transmitting PMeV-Mx to C. papaya 'Maradol'.
\end{abstract} if they carried PMeV-Mx. The Cicadellidae family (Hemiptera) was the most diverse and abundant, and Empoasca papayae was the most abundant species and had the highest virus titers. PMeV-Mx transmission
Keywords: viruses, papaya meleira virus, Empoasca papaya, insect vector, RT-qPCR
Mexico is one of the leading papaya (Carica papaya $\mathrm{L}$.) producers worldwide, and it is the largest exporter of this fruit to the United States (FAOSTAT 2018). The production areas of papaya are predominantly in the central and south-southeastern regions of Mexico. In 2012, papaya meleira virus (PMeV), the causal agent of sticky disease, was detected in papaya orchards in the Yucatan Peninsula. Since then, PMeV has spread from southern Mexico to 29 different municipalities in 10 (out of 20) papaya-producing states (PérezBrito et al. 2012).

Sticky disease was first detected in the late 1980s in Brazil (Rodrigues et al. 1989). To date, this disease has been reported only in Brazil and Mexico, but it could eventually spread to other papayaproducing countries in the American continent.

The causative agent of sticky disease was identified in Brazil as $\mathrm{PMeV}$, an isometric virus with a double-stranded RNA (dsRNA) genome (Maciel-Zambolim et al. 2003; Tavares et al. 2004). Later, in Brazil, sticky disease was found to be associated with a double infection of PMeV, a Totiviridae virus, and PMeV2, an umbra-like virus with a single-stranded RNA (ssRNA) genome (Sá Antunes et al. 2016). However, in a Mexican variant of PMeV (PMeV-Mx), a 1,154-bp partial sequence, encoding a putative RNA-dependent RNA polymerase (RdRp), was found to be more similar to the RdRp of papaya virus $Q$, a new papaya virus discovered in Ecuador (QuitoAvila et al. 2015), and to the RdRps of PMeV2 and other members of the genus Umbravirus (Sá Antunes et al. 2016; Zamudio-Moreno et al. 2015). It is important to note that a set of primers, the design of which was based on the PMeV-Mx sequence, amplified fragments

${ }^{\dagger}$ Corresponding author: D. Pérez-Brito; daisypb@ cicy.mx

The author(s) declare no conflict of interest.

Accepted for publication 14 March 2019.

(C) 2019 The American Phytopathological Society from both Brazilian and Mexican sticky disease-infected plants (Zamudio-Moreno et al. 2015).

During the economic cycle of the crop, both in Brazil and in Mexico, it has been detected, by the observation of sticky disease symptoms or by molecular tests, that PMeV infects between 20 and $50 \%$ of the orchards, but the disease incidence can sometimes increase to 100\% (Abreu et al. 2015; Pérez-Brito et al. 2012; Ventura et al. 2004).

The main problem with $\mathrm{PMeV}$ is not only the quantitative but also the qualitative loss of production, because the fruits affected by exudation and subsequent oxidation of latex, which are the main symptoms of sticky disease, are no longer suitable for commercialization (Abreu et al. 2015; García-Cámara et al. 2018).

There have been some studies to determine the ways in which this disease is transmitted. Consensus has been reached that certain agricultural practices, such as fruit harvesting, may be responsible for the spread of PMeV in orchards (Abreu et al. 2015; Ventura et al. 2004). The mechanical transmission of $\mathrm{PMeV}$ occurs when latex of diseased plants is injected into the stems of healthy papayas (Maciel-Zambolim et al. 2003; Rodrigues et al. 2009). In addition, PMeV transmission between generations via contaminated papaya seeds has been demonstrated in cultivar Maradol (Tapia-Tussell et al. 2015). Recently, it was also shown that watermelon is an alternative host of this virus (GarcíaCámara et al. 2018).

There are few studies on the transmission of this virus by insect vectors. There is some evidence of an airborne vector of $\mathrm{PMeV}$, based on studies of the field spread pattern of papaya sticky disease (Abreu et al. 2015; Rodrigues et al. 1989). dsRNA of PMeV was detected at 6 months, and sticky disease symptoms were presented at 8 months, after healthy papaya plants were exposed to Bemisia tabaci type B, collected from PMeV-infected papaya seedlings (Vidal et al. 2003), although the virus was not detected in this potential vector, which is not a papaya pest. Later, in another study, a whitefly species, Trialeurodes variabilis, which is a pest of Brazilian papaya, was unable to transmit this virus from $\mathrm{PMeV}$-inoculated papaya to healthy papayas in greenhouse conditions, even though adult whiteflies and 
their nymphs, collected from a greenhouse, showed the presence of viral dsRNA, indicating that they had acquired $\mathrm{PMeV}$ during the course of the experiment (Rodrigues et al. 2009). Recently, leafhoppers (Hemiptera: Cicadellidae) appeared as potential insect vectors of the sticky disease virus in Brazil, because their distribution in the crop is related to the distribution of this disease (Gouvea et al. 2018).

Given the relevance of sticky disease to Mexican papaya crops and the importance of the crop itself, the aim of this research was to perform an extensive study to identify potential insect vectors of PMeVMx and demonstrate the transmission of the virus by these insects. Information derived from this work is essential for the development of effective management strategies to control sticky disease.

\section{Materials and Methods}

Insect collection. Adult insects were collected on different dates at five different papaya orchards in south-southeast of Mexico. Collections were made from one experimental orchard, located in San Jose Kuche, Yucatan $(21.063659,-89.332828)$, from February to July 2015 and from four commercial orchards, located in Temozon, Yucatan (20.9090197, -88.1895908), Tizimin, Yucatan (21.365876, -87.720415), Alfredo Bonfil, Campeche (19.5479081, -90.180298), and Rancho El Rocio, Frontera Hidalgo, Tapachula, Chiapas (14.772763, -92.231419), from February to November 2016.

All collections were made using sweeping nets and mouth aspirators, and insects were collected from papaya plants and weeds around and between papaya plants. Samples were placed in 50-ml Falcon tubes with $70 \%$ ethanol and stored at $4{ }^{\circ} \mathrm{C}$ until use. At the laboratory, insects were observed under a $4 \times$ stereoscope (Swift, China) and initially classified up to the family taxonomic level, according to their morphology. From each morphologically different sample, three specimens were collected and sent to be identified taxonomically by Héctor Enrique Vega Ortiz (Head of Entomology and Acarology Department, National Phytosanitary Reference Center, Mexico). Finally, the samples were counted to obtain abundancy and frequency data.

Morphological and molecular identification of insects. The morphological identification of insects was carried out at the Entomology and Acarology Department, National Phytosanitary Reference Center of the National Service of Health, Safety, and Agri-Food Quality (SENASICA), Mexico.

For insect molecular identification, mitochondrial DNA was ex tracted from single samples (replicated three times), with hexadecyltrimethylammonium bromide extraction buffer $(2 \%$ with $5 \mathrm{M} \mathrm{NaCl})$, according to the protocol of Doyle and Doyle (1987), modified by the Ministry of Agriculture, Livestock, Rural Development, Fisheries and Food (SAGARPA 2017). The quantity and quality of DNA were estimated using a NanoDrop 2000 spectrophotometer (Thermo Scientific, Waltham, MA). DNA integrity was analyzed by electrophoresis in $0.8 \%(\mathrm{w} / \mathrm{v})$ agarose gels in $1 \times$ Tris/borate/EDTA buffer (TBE) and ethidium bromide staining. Polymerase chain reaction (PCR) amplifications were performed using universal primers, based on genomic regions of the cytochrome oxidase c subunit 1 gene, to amplify a 710-bp DNA fragment (LCO1490, 5'-GGTCAACAAATCA TAAAGATATTGG-3'; HC02198, 5'-TAAACTTCAGGGTGAC CAAAAAATCA-3') (Folmer et al. 1994). The following cycling conditions were used: $1 \mathrm{~min}$ denaturation at $94^{\circ} \mathrm{C}$; four cycles of $94^{\circ} \mathrm{C}$

A

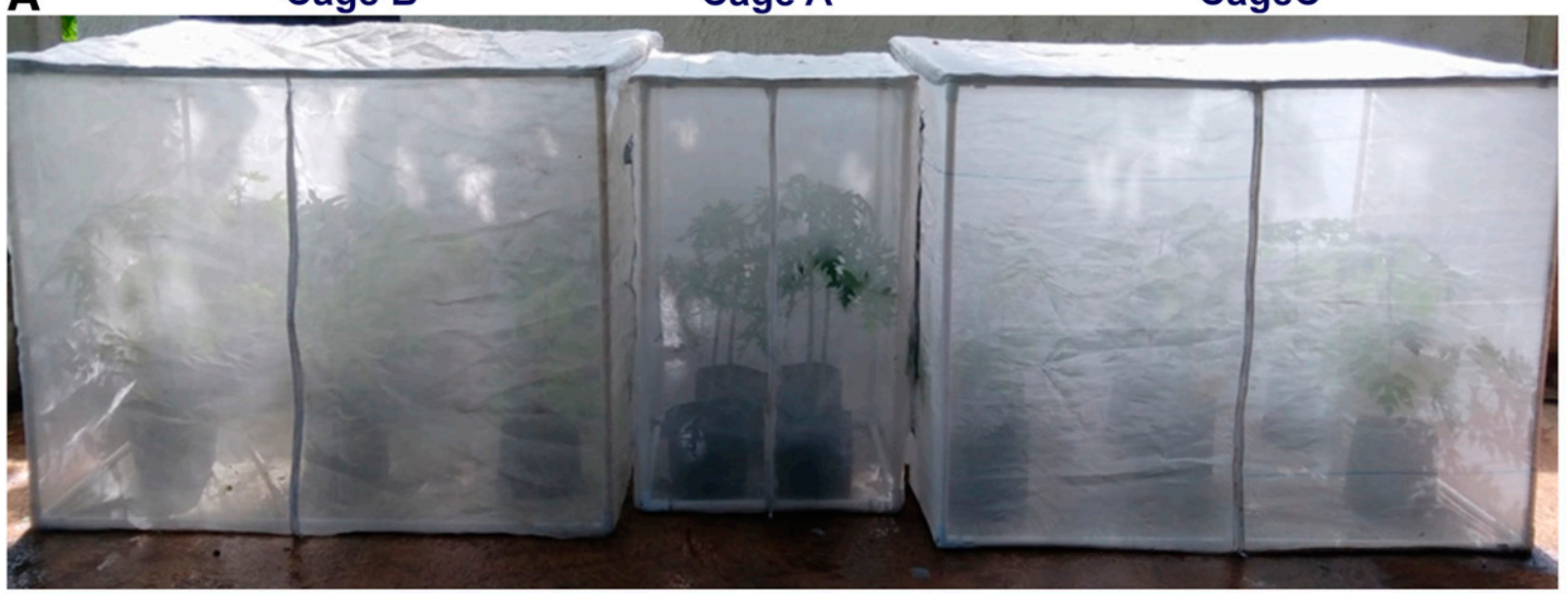

B

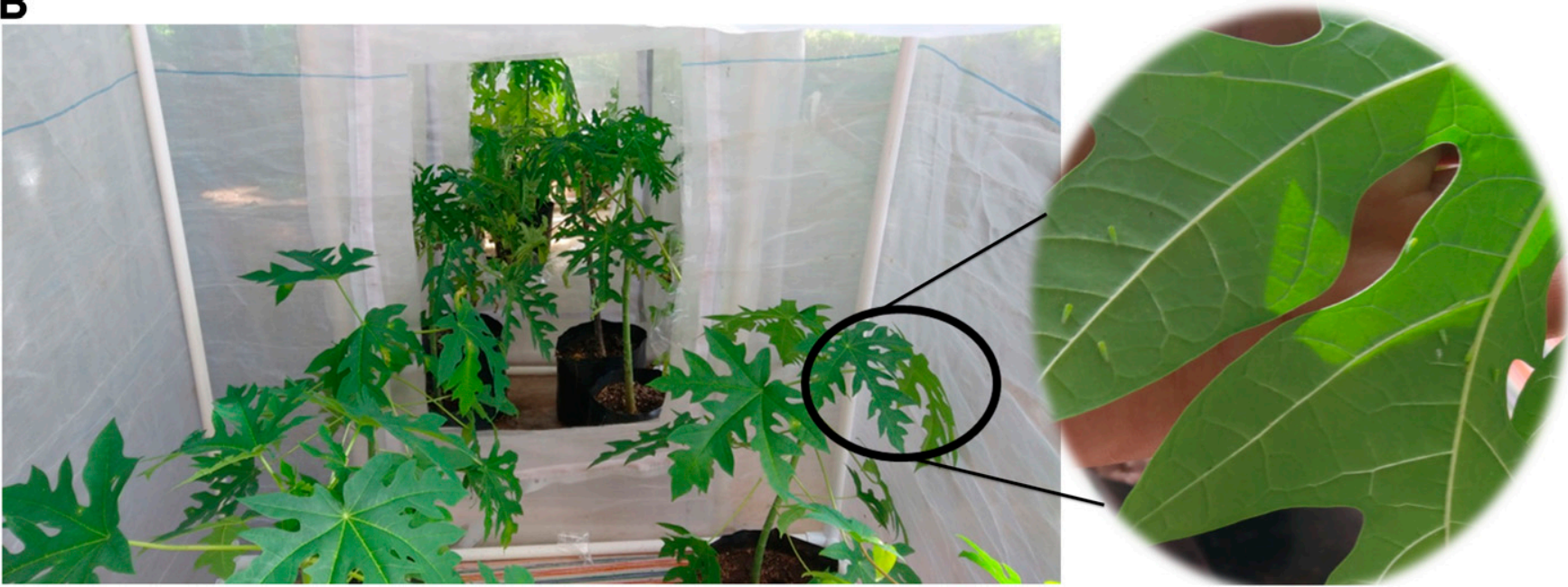

Fig. 1. Experimental transmission of papaya meleira virus Mexican variant (PMeV-Mx) by Empoasca papayae. A, Insect-proof cages for transmission experiments (cage $A$ with PMeV-Mx-infected papaya plants, cages B and C with healthy papaya plants). B, Inside view of the insect-proof cages after removing the mesh between cages, and viruliferous leafhoppers on the leaves of healthy papaya plants. 
for $30 \mathrm{~s}, 45^{\circ} \mathrm{C}$ for $90 \mathrm{~s}$, and $72^{\circ} \mathrm{C}$ for $1 \mathrm{~min}$; and 35 cycles of $94^{\circ} \mathrm{C}$ for $30 \mathrm{~s}, 51^{\circ} \mathrm{C}$ for $90 \mathrm{~s}$, and $72^{\circ} \mathrm{C}$ for $10 \mathrm{~min}$. PCR products were visualized by electrophoresis in $1.5 \%(\mathrm{w} / \mathrm{v})$ agarose gels in $1 \times \mathrm{TBE}$ and ethidium bromide staining to detect the presence of the target band. One or more RT-PCR products were purified using the Wizard SV Gel and PCR Clean-Up System (Promega, Madison, WI) and were sequenced in both directions by Macrogen, South Korea. Sequences obtained were analyzed using the Basic Local Alignment Search Tool (BLAST), accessed via the National Center for Biotechnology Information (NCBI) website.

Screening of PMeV-Mx in insects by quantitative reverse transcription PCR (RT-qPCR) and sequencing. Three randomly selected individuals of each identified insect species from each of the five collection sites were tested by RT-qPCR amplification for the presence of PMeV-Mx. This experiment was replicated two times. The total RNA was extracted from $3.0 \mathrm{mg}$ of insect tissue according to the TRIzol procedure (Invitrogen, Carlsbad, CA) and treated with DNase I (Invitrogen), and the RNA quantity and quality were measured using a NanoDrop 2000 spectrophotometer (Thermo Scientific). The RNA integrity was analyzed by electrophoresis in $0.8 \%$ (w/v) agarose gels in $1 \times \mathrm{TBE}$ and ethidium bromide staining. The total RNA concentration of each sample was adjusted to $1.0 \mu \mathrm{g} / \mu \mathrm{l}$, and then the RNAs were reverse transcribed using M-MLV reverse transcription (Invitrogen) and random primers, according to the manufacturer's instructions. The concentration of each cDNA sample was adjusted to $20 \mathrm{ng} / \mu \mathrm{l}$ (Kuang et al. 2018). The presence or absence of PMeV-Mx was determined by RT-qPCR amplification. Primers, TaqMan probe, and cycling conditions were designed previously at GeMBio Laboratory (García-Cámara et al. 2018). RT-qPCR was performed in a StepOne Real-Time PCR System (Applied Biosystems, Warrington, U.K.). RT-qPCR was conducted in 48-well reaction plates using $20 \mu$ l of reaction mix, containing $10 \mu \mathrm{l}$ of TaqMan Universal Master Mix II (Applied Biosystems), $0.4 \mu \mathrm{l}$ of each of primer (each at $0.2 \mu \mathrm{M}), 1.2 \mu \mathrm{l}$ of TaqMan probe $(0.75 \mu \mathrm{M}), 0.4 \mu \mathrm{l}$ of Rox reference dye $(500 \mathrm{nM})$, and $3 \mu \mathrm{l}(20 \mathrm{ng} / \mu \mathrm{l})$ of the template cDNA of each sample. The thermal profile was set with the initial denaturation at $95^{\circ} \mathrm{C}$ for $5 \mathrm{~min}$, followed by 40 cycles of $95^{\circ} \mathrm{C}$ for $15 \mathrm{~s}$ and $60^{\circ} \mathrm{C}$ for $30 \mathrm{~s}$. The RNA from PMeV-Mxinfected papaya (positive control), RNA from healthy plants (negative control), and a nontemplate control (NTC) were included in each experiment. All samples were tested in triplicate wells, and sample thresholds, baseline values, and reaction efficiency values were calculated automatically in the StepOne Real-Time PCR System manager software (Applied Biosystems). Samples with a threshold cycle $\left(C_{T}\right)$ value greater than 32 were considered negative (Sieburth et al. 2009; Stansly et al. 2014). The actin gene was used as an internal control to verify the presence of intact RNA (Galetto et al. 2013).

In addition, the total RNA extracted from insect samples, as described above, was amplified with specific primers, based on the genomic regions of the PMeV-Mx RdRp gene, to obtain a 491-bp DNA fragment (NCBI accession KF781635.1) (CB38, 5'-AGCGCAT CTCGTTCTGCCA-3'; CB39， 5'-GCCCGGATATACCGGCCT$\left.3^{\prime}\right)$ (Zamudio-Moreno et al. 2015). The RNAs were reverse transcribed, as described previously. The cDNA was amplified with Taq DNA polymerase (Invitrogen), using the following cycling conditions: 5 min denaturation at $95^{\circ} \mathrm{C}, 40$ cycles of $95^{\circ} \mathrm{C}$ for $1 \mathrm{~min}$, $60^{\circ} \mathrm{C}$ for $1 \mathrm{~min}, 72^{\circ} \mathrm{C}$ for $1 \mathrm{~min}$, and a final extension at $72^{\circ} \mathrm{C}$ for $10 \mathrm{~min}$. RT-PCR products were visualized by electrophoresis in $1.5 \%(\mathrm{w} / \mathrm{v})$ agarose gels in $1 \times \mathrm{TBE}$ and ethidium bromide staining to detect the target band. RT-PCR products were purified using the Wizard SV Gel and PCR Clean-Up System (Promega) and were

Table 1. Taxonomic classification and detection of PMeV-Mx in insects collected from papaya fields between 2015 and $2016^{\mathrm{a}}$

\begin{tabular}{|c|c|c|c|c|c|}
\hline Order & Family & Genera & Location & Host & $\begin{array}{l}\text { Quantification of PMeV-Mx } \\
\text { by RT-qPCR }(p g / \mu l)\end{array}$ \\
\hline Araneae & $\ldots$ & $\ldots$ & $\mathrm{A}, \mathrm{B}, \mathrm{C}, \mathrm{D}$ & Carica papaya & 0.0 \\
\hline Coleoptera & Mordellidae & Mordella sp. & A & Weeds & 0.0 \\
\hline Coleoptera & Mordellidae & Madarellus undulatus & A & Weeds & 0.0 \\
\hline Diptera & Lauxaniidae & $\ldots$ & $\mathrm{A}, \mathrm{B}, \mathrm{C}, \mathrm{D}$ & Weeds & 0.0 \\
\hline Hemiptera & Coreidae & Amblypelta nitida & A, B & C. papaya & 0.0 \\
\hline Hemiptera & Acanaloniidae & Acanalonia sp. & $\mathrm{A}, \mathrm{C}$ & Weeds & 0.0 \\
\hline Hemiptera & Aphididae & Aphis sp. & A, B & Weeds & $1.813( \pm 0.13)$ \\
\hline Hemiptera & Aphididae & Uroleucon taraxaci & A & Weeds & $1.843( \pm 0.04)$ \\
\hline Hemiptera & Cicadellidae & Agallia constricta & $\mathrm{A}, \mathrm{C}$ & C. papaya & $2.049( \pm 0.09)$ \\
\hline Hemiptera & Cicadellidae & Agalliopsis novella & $\mathrm{A}, \mathrm{B}, \mathrm{C}$ & C. papaya & $1.980( \pm 0.16)$ \\
\hline Hemiptera & Cicadellidae & Apogonalia sp. & $\mathrm{A}, \mathrm{C}$ & Weeds & 0.0 \\
\hline Hemiptera & Cicadellidae & Balclutha abdominalis & A & Weeds & 0.0 \\
\hline Hemiptera & Cicadellidae & Coelidia sp. & A, B & Weeds & 0.0 \\
\hline Hemiptera & Cicadellidae & Draeculacephala soluta & $\mathrm{A}, \mathrm{B}, \mathrm{C}$ & Weeds & $1.943( \pm 0.07)$ \\
\hline Hemiptera & Cicadellidae & Empoasca papayae & $\mathrm{A}, \mathrm{B}, \mathrm{C}, \mathrm{D}, \mathrm{E}$ & C. papaya & $2.207( \pm 0.04)$ \\
\hline Hemiptera & Cicadellidae & Flexamia sp. & A & Weeds & 0.0 \\
\hline Hemiptera & Cicadellidae & Graphogonalia sp. & $\mathrm{A}, \mathrm{B}, \mathrm{C}, \mathrm{D}$ & Weeds & 0.0 \\
\hline Hemiptera & Cicadellidae & Gypona sp. & $\mathrm{A}$ & Weeds & 0.0 \\
\hline Hemiptera & Cicadellidae & Homalodisca sp. & $\mathrm{A}, \mathrm{B}, \mathrm{C}$ & Weeds & 0.0 \\
\hline Hemiptera & Cicadellidae & Hortensia sp. & $\mathrm{A}, \mathrm{B}, \mathrm{C}$ & Weeds & $1.893( \pm 0.11)$ \\
\hline Hemiptera & Cicadellidae & Macrosteles sp. & $\mathrm{A}$ & Weeds & 0.0 \\
\hline Hemiptera & Cicadellidae & Ponana sp. & A & Weeds & 0.0 \\
\hline Hemiptera & Cicadellidae & Texananus sp. & $\mathrm{A}, \mathrm{B}$ & Weeds & 0.0 \\
\hline Hemiptera & Cicadellidae & Xyphon sp. & $\mathrm{A}, \mathrm{B}, \mathrm{C}$ & Weeds & $1.973( \pm 0.09)$ \\
\hline Hemiptera & Cixiidae & Oecleus sp. & A & Weeds & 0.0 \\
\hline Hemiptera & Membracidae & Cyrtolobus sp. & A & Weeds & 0.0 \\
\hline Hemiptera & Miridae & Reuteroscopus ornatus & $\mathrm{A}, \mathrm{B}, \mathrm{C}, \mathrm{D}$ & C. papaya & 0.0 \\
\hline Hemiptera & Miridae & Proba vittiscutis & $\mathrm{A}, \mathrm{B}, \mathrm{C}, \mathrm{D}$ & C. papaya & 0.0 \\
\hline Hemiptera & Psyllidae & Euphalerus sp. & A, D & C. papaya & 0.0 \\
\hline Lepidoptera & Gelechiidae & $\ldots$ & A, B, C, D & Weeds & 0.0 \\
\hline Neuroptera & Chrysopidae & Chrysoperla carnea & C, D & C. papaya & 0.0 \\
\hline
\end{tabular}

a PMeV-Mx = papaya meleira virus Mexican variant, and RT-qPCR = quantitative reverse transcription polymerase chain reaction. Locations: A = experimental papaya orchard in San José Kuché, Conkal, Yucatán (21.063659, -89.332828); B = commercial papaya orchard in Alfredo Bonfil, Campeche (19.5479081, -90.180298); C = commercial papaya orchard in Colonia Yucatán, Tizimín, Yucatán (21.365876, -87.720415); D = commercial papaya orchard in Temozón, Yucatán (20.9090197, -88.1895908); and E = commercial papaya orchard in Rancho El Rocio, Frontera Hidalgo, Tapachula, Chiapas (14.772763, -92.231419). 
sequenced in both directions (Macrogen). The sequences obtained were analyzed using BLAST, accessed via the NCBI website.

Empoasca papayae colony establishment. Once the frequency and abundance of all PMeV-Mx-positive insect species collected were known, the species that was PMeV-Mx positive all of the time, had the highest virus titer, and was the most abundant in all of the papaya fields was selected for the transmission study. To establish a colony for the transmission test, 200 adult insects of E. papayae were collected from healthy field-papaya plants in a commercial orchard, located in Muna (20.440599, -89.791291), Yucatan. Insects were placed inside insect-proof cages $(70 \mathrm{~cm}$ wide $\times 70 \mathrm{~cm}$ long $\times$ $130 \mathrm{~cm}$ high), located inside a biosecurity greenhouse at the Yucatan Center for Scientific Research (CICY). Insects were maintained on healthy papaya cultivar Maradol plants at ambient temperature (25 to $38^{\circ} \mathrm{C}$ ), with a photoperiod of $16 \mathrm{~h}$ of light. The purity of the insect colony was confirmed by determining the sequence of the cytochrome oxidase I mitochondrial gene, as previously described. To ensure an insect colony free of $\mathrm{PMeV}$ and phytoplasmas (phytopathogens commonly transmitted by this insect species), the nymphs and adults of the fifth generation descended from the original individuals collected were tested every 21 days for PMeV-Mx by RT-qPCR and phytoplasma by nested PCR (Tapia-Tussell et al. 2012).

Plant material and virus source. Papaya plants of cultivar Maradol grown from certified seeds were used in all experiments. Sixty plants were grown in commercial substrate, placed inside a biosecurity greenhouse at CICY, and maintained at ambient temperature (25 to $38^{\circ} \mathrm{C}$ ) with a photoperiod of $16 \mathrm{~h}$ of light. All plants were tested for PMeV by RT-qPCR and phytoplasma by nested PCR at 30, 60 and 90 days postgermination.

Latex samples of immature green fruits from sticky diseased papaya plants, located in San José Kuché, municipality of Conkal, Yucatan, Mexico, were obtained by wounding the fruit surfaces. To verify the PMeV presence in this latex, RNA was extracted from $50.0 \mathrm{mg}$ of leaf tissue, as described in protocol 1 (Tavares et al.2004), followed by electrophoresis in $1 \%(\mathrm{w} / \mathrm{v})$ agarose gels in $1 \times \mathrm{TBE}$, searching for presence of PMeV dsRNA (9 kb) and PMeV2 ssRNA $(4.5 \mathrm{~kb})$ bands. In addition, RT-PCR was performed on this RNA using primers, $\mathrm{CB} 38$ and CB39, which are specific to the PMeV-Mx RdRp gene (Zamudio-Moreno et al. 2015).

To obtain PMeV-Mx-infected papaya plants, to be used as a virus source in transmission tests, eight healthy greenhouse-grown 3month-old papaya plants were inoculated with $\mathrm{PMeV}-\mathrm{Mx}$-infected latex. PMeV-Mx-infected latex was diluted at $1: 1(\mathrm{v} / \mathrm{v})$ in $1 \times$ phosphate-buffered saline, $\mathrm{pH}$ 7.4. The plants were inoculated by injecting $20 \mu \mathrm{l}$ of the diluted latex solution into the stem near the apex using a sterile syringe (Abreu et al. 2012). These plants were placed inside an insect-proof cage (cage A).
Quantification of PMeV-Mx by RT-qPCR. The amount of PMeV-Mx-RNA in inoculated papaya plants was determined by RT-qPCR. Primers, TaqMan probe, and cycling conditions were designed previously at the GeMBio Laboratory (García-Cámara et al. 2018). The total RNA extraction, RNA quality and quantity assessment, and total RNA reverse transcription were performed as described previously. To estimate the concentration $(\mathrm{pg} / \mu \mathrm{l})$ of $\mathrm{PMeV}$ Mx-RNA, 10-fold serial dilutions of the Synthetic Positive Control Template for Standard Curve (Primer Design, Southampton, U.K.) were included in the RT-qPCR to obtain a standard curve. The standard curve template was an 86-bp fragment of the PMeV-Mx polymerase gene, and dilution concentrations were confirmed with a NanoDrop 2000 spectrophotometer (Thermo Scientific). For quantification, PMeV-Mx-RNA concentrations $(\mathrm{pg} / \mu \mathrm{l})$ were calculated based on the specific standard curve values generated in this reaction, which reproduced a linear relationship between the $C_{T}$ value and the amount of total target concentrations in the samples. Real-time RTPCR was performed in a StepOne Real-Time PCR System (Applied Biosystems) in 48-well reaction plates using $20 \mu \mathrm{l}$ of reaction mix containing $10 \mu \mathrm{l}$ of TaqMan Universal Master Mix II (Applied Biosystems), $0.4 \mu \mathrm{l}$ each of primer (each at $0.2 \mu \mathrm{M}$ ), $1.2 \mu \mathrm{l}$ of TaqMan probe $(0.75 \mu \mathrm{M}), 0.4 \mu \mathrm{l}$ of Rox reference dye $(500 \mathrm{nM})$, and $3 \mu \mathrm{l}$ $(20 \mathrm{ng} / \mu \mathrm{l})$ of the template cDNA of each sample. The thermal profile was set with the initial denaturation at $95^{\circ} \mathrm{C}$ for $5 \mathrm{~min}$, followed by 40 cycles of $95^{\circ} \mathrm{C}$ for $15 \mathrm{~s}$ and $60^{\circ} \mathrm{C}$ for $30 \mathrm{~s}$. The RNA from PMeV-Mxinfected papaya (positive control), RNA from papaya healthy plants (negative control), and NTC were included in each experiment. All samples were tested in triplicate wells, and sample thresholds, baseline values, and reaction efficiency values were calculated automatically in the StepOne Real-Time PCR System manager software (Applied Biosystems). Samples with a $C_{T}$ value greater than 32 were considered negative (Sieburth et al. 2009; Stansly et al. 2014). The actin gene was used as an internal control and to verify the presence of intact RNA (Galetto et al. 2013).

PMeV transmission tests. The PMeV-Mx-infected papaya plants at 14 days postinoculation (dpi) (from cage A), were used as viral sources. After a 24-h starvation period, 200 adults from an $E$. papayae colony were placed inside cage $\mathrm{A}$ to be exposed to infected papaya plants for virus acquisition. When the optimal acquisition access period (AAP) and inoculation access period (IAP) are unknown (as in this case), long acquisition and inoculation times should provide the maximum transmission efficiency (Bosco and Tedeschi 2013). To determine the optimal AAP of PMeV-Mx by E. papayae, the amount of PMeV-Mx-RNA in these leafhoppers was measured, from $6 \mathrm{~h}$ after exposure to 14 days after exposure (dae) to PMeVinfected papaya plants, with intervals of $6 \mathrm{~h}$ in the first $24 \mathrm{~h}$ and then every $24 \mathrm{~h}$ thereafter. In each interval, two replicates were taken with

Table 2. Number of individual insects collected from papaya fields (locations A to E, hosts P and W) between 2015 and 2016, testing positive for PMeV-Mx by RT-qPCR ${ }^{\mathrm{a}}$

\begin{tabular}{|c|c|c|c|c|c|c|c|c|c|c|c|c|}
\hline \multirow[b]{4}{*}{ Insect genus/species } & \multicolumn{4}{|c|}{2015} & \multicolumn{8}{|c|}{2016} \\
\hline & \multirow{2}{*}{\multicolumn{2}{|c|}{$\begin{array}{c}\text { February } \\
\mathbf{A}\end{array}$}} & \multirow{2}{*}{\multicolumn{2}{|c|}{$\frac{\text { July }}{\text { A }}$}} & \multicolumn{6}{|c|}{ February } & \multirow{2}{*}{\multicolumn{2}{|c|}{$\begin{array}{c}\text { July } \\
\text { B }\end{array}$}} \\
\hline & & & & & & & & & & & & \\
\hline & $\overline{\mathbf{P}}$ & $\overline{\mathbf{W}}$ & $\overline{\mathbf{P}}$ & $\overline{\mathbf{W}}$ & $\overline{\mathbf{P}}$ & $\overline{\mathbf{W}}$ & $\mathbf{P}$ & $\overline{\mathbf{W}}$ & $\bar{P}$ & $\overline{\mathbf{W}}$ & $\mathbf{P}$ & $\mathbf{W}$ \\
\hline Draeculacephala soluta & 0 & 7 & 0 & 10 & 0 & 2 & 3 & 3 & 0 & 7 & 0 & 2 \\
\hline Hortensia spp. & 0 & 9 & 0 & 8 & 0 & 1 & 0 & 2 & 1 & 2 & 0 & 2 \\
\hline Agalliopsis novella & 5 & 0 & 3 & 0 & 5 & 0 & 1 & 0 & 1 & 0 & 9 & 0 \\
\hline Xyphon spp. & 1 & 5 & 3 & 7 & 0 & 0 & 0 & 9 & 0 & 1 & 0 & 0 \\
\hline Agallia constricta & 2 & 0 & 2 & 0 & 5 & 0 & 14 & 0 & 11 & 0 & 13 & 0 \\
\hline Empoasca papayae & 17 & 0 & 6 & 0 & 16 & 0 & 43 & 0 & 34 & 0 & 12 & 0 \\
\hline Aphis spp. & 10 & 110 & 0 & 9 & 0 & 0 & 0 & 0 & 0 & 0 & 0 & 0 \\
\hline
\end{tabular}

a $\mathrm{PMeV}-\mathrm{Mx}=$ papaya meleira virus Mexican variant, and $\mathrm{RT}-\mathrm{qPCR}=$ quantitative reverse transcription polymerase chain reaction. Locations: A = experimenta papaya orchard in San José Kuché, Conkal, Yucatán (21.063659, -89.332828); B = commercial papaya orchard in Alfredo Bonfil, Campeche (19.5479081, -90.180298); C = commercial papaya orchard in Colonia Yucatán, Tizimín, Yucatán (21.365876, -87.720415); D = commercial papaya orchard in Temozón, Yucatán (20.9090197, -88.1895908); and E = commercial papaya orchard in Rancho El Rocio, Frontera Hidalgo, Tapachula, Chiapas (14.772763,

-92.231419). Hosts: $\mathrm{P}=$ Carica papaya $\mathrm{L}$., and $\mathrm{W}=$ different weed species. 
two insects each. This analysis was performed by RT-qPCR under the conditions previously described.

Two more cages (cages B and C) were placed on either side of cage A (Fig. 1A). Each of these cages contained six healthy greenhousegrown papaya plants. All C. papaya 'Maradol' plants that were used as recipients for the transmission assays had been evaluated by RTqPCR to ensure that they were healthy. PMeV-Mx-viruliferous leafhoppers, confined inside cage $\mathrm{A}$, were released to adjacent cages at 5 dae to PMeV-infected papaya plants. The insect-proof meshes that separated cage A from cages B and C were removed, and the leaves of PMeV-Mx-infected papaya plants were shaken, allowing the passage of viruliferous insects from infected to healthy plants located in the adjacent cages (Fig. 1B). Detection and quantification of PMeV$\mathrm{Mx}$ was performed by RT-qPCR from new leaves of all healthyreceptor papaya plants at $7,14,21,28,35$, and 60 dae, to confirm virus infection and the ability of E. papayae to transmit PMeV-Mx. The total RNA extraction, reverse transcription, and quantitative amplification were performed under the conditions previously described. In addition, the total RNA extracted from the receptor papaya plant samples was amplified with specific primers, based on the genomic regions of the PMeV-Mx RdRp gene, as described previously (Zamudio-Moreno et al. 2015), and sequenced.

Fourteen days after the release of the insects in boxes B and C, plants were treated with imidacloprid (Confidor 200 SL, Bayer CropScience LP) to eliminate the insects, transferred to an insectproof greenhouse, and observed for the development of sticky disease symptoms. Experiments were replicated three times. In these experiments, two controls were used: box D, where six healthy papaya plants were placed, without insects; and box E, where six healthy papaya plants were placed and exposed to 100 adult insects of E. papayae free of PMeV-Mx. All papaya plants used as controls were also obtained from certified and tested seeds, free of PMeV-Mx.

Acquisition of PMeV by $E$. papaya nymphs. To test for PMeVMx acquisition by nymphs, E. papayae adults reared on healthy papayas were isolated with $\mathrm{PMeV}-\mathrm{Mx}$-infected papaya plants in cages, measuring $70 \times 70 \times 130 \mathrm{~cm}$, for 15 days. Adults insect were removed, and plants were monitored for the emergence of nymphs from hatching eggs. Following the development of insects, the first to fifth instar nymphs from the infected plants were collected for subsequent virus detection. The total RNA from the first to fifth instar nymphs (five each instar) was extracted and reverse transcribed, and nymphs were assayed by RT-qPCR to analyze the PMeV-Mx acquisition. Experiments were replicated three times.

\section{Results}

In papaya cultivar Maradol fields, at different locations in the Yucatán Peninsula and Chiapas, 2,795 adult insect samples were collected. Both morphological and molecular identification showed a high diversity, which included 31 genera belonging to the orders
Araneae, Diptera, Coleoptera, Hemiptera, Lepidoptera and, Neuroptera (Table 1).

The Cicadellidae family (Hemiptera) was the most diverse and abundant family. Fifteen different genera and/or species of this family were identified, of which 12 (Apogonalia sp., Coelidia sp., Draeculacephala soluta Gibson, Flexamia sp., Graphogonalia sp., Gypona sp., Homalodisca sp., Hortensia sp., Macrosteles sp., Ponana sp., Texananus sp., and Xyphon sp.) were collected from both papaya plants and the weeds surrounding the orchards. Three genera and/or species (Agalliopsis novella Say, Agallia constricta Van Duzee, and E. papayae Oman) were found only in papaya plant leaves (Table 2). In all samplings, the most abundant species within the Cicadellidae family was E. papayae.

Detection of PMeV-Mx in insects. PMeV-Mx was detected in six (D. soluta, A. novella, Xyphon sp., Hortensia sp., A. constricta, and E. papayae) of the 15 species or genera of Cicadellidae and in one genus and one species (Aphis sp. and Uroleucon taraxaci) of the Aphididae family. $\mathrm{C}_{\mathrm{T}}$ values varied from 28 to 30 , which means that these hemipteran species are carriers of PMeV-Mx. In addition, a PCR product (491 bp) of each was sample sequenced, confirming the expected viral sequence, with $97 \%$ identity to a $\mathrm{PMeV}$ hypothetical protein and RdRp genes (KF214786.1). In this study, E. papayae showed a higher virus titer than did other insects tested for the presence of $\mathrm{PMeV}$, so it was selected for $\mathrm{PMeV}-\mathrm{Mx}$ transmission experiments.

Establishing $\boldsymbol{E}$. papaya populations. The insects used to establish the colony of E. papayae were identified morphologically at the National Phytosanitary Reference Center, SENASICA, Mexico, and five representative samples were deposited in that institution (deposit number CNRF-12.12-9). In addition, their sequences obtained by molecular identification were analyzed and deposited in GenBank (KY931021.1, KY931022.1, KY931023.1, and KY931024.1).

The $E$. papayae colony was successfully established in insectproof cages, located inside a biosecurity greenhouse at CICY, using healthy plants of $C$. papaya 'Maradol' as hosts, under the conditions established in this study.

The molecular diagnoses, made every 21 days, of the samples of nymphs and adult insects of E. papayae were negative to PMeV$\mathrm{Mx}$ and negative to phytoplasmas.

Transmission of PMeV-Mx by $E$. papayae. When quantifying the viral titer by RT-qPCR in all papaya plants previously inoculated with PMeV-Mx and used as a source of virus acquisition, it was observed that 14 days after inoculation (at the beginning of the transmission test) the average viral titer was $9.15( \pm 0.089) \mathrm{ng} / \mu \mathrm{l}$ of PMeV-Mx RNA from $20 \mathrm{ng} / \mu \mathrm{l}$ of cDNA.

On the other hand, when quantifying the viral titer of PMeV-Mx in the colony of E. papayae exposed to infected plants, it was found that $E$. papayae became a carrier of this virus $6 \mathrm{~h}$ after exposure. All insects tested were positive to $\mathrm{PMeV}$, with an estimated value of 1.813

Table 2. (Continued from previous page)

\begin{tabular}{|c|c|c|c|c|c|c|c|c|c|c|c|c|}
\hline \multicolumn{12}{|c|}{2016} & \multirow[b]{4}{*}{ Total } \\
\hline \multicolumn{6}{|c|}{ July } & \multicolumn{6}{|c|}{ November } & \\
\hline \multicolumn{2}{|c|}{ C } & \multicolumn{2}{|c|}{ D } & \multicolumn{2}{|c|}{$\mathbf{E}$} & \multicolumn{2}{|c|}{ B } & \multicolumn{2}{|c|}{ C } & \multicolumn{2}{|c|}{ D } & \\
\hline $\mathbf{P}$ & $\mathbf{W}$ & $\mathbf{P}$ & $\mathbf{W}$ & $\mathbf{P}$ & $\overline{\mathbf{W}}$ & $\mathbf{P}$ & $\mathbf{W}$ & $\mathbf{P}$ & $\mathbf{W}$ & $\mathbf{P}$ & $\mathbf{W}$ & \\
\hline 0 & 8 & 0 & 3 & 0 & 0 & 0 & 1 & 3 & 12 & 0 & 2 & 63 \\
\hline 3 & 8 & 1 & 4 & 0 & 0 & 0 & 3 & 5 & 10 & 0 & 4 & 63 \\
\hline 9 & 0 & 4 & 0 & 0 & 0 & 15 & 0 & 12 & 0 & 9 & 0 & 83 \\
\hline 0 & 9 & 0 & 3 & 0 & 0 & 0 & 0 & 2 & 16 & 0 & 12 & 68 \\
\hline 11 & 0 & 8 & 0 & 0 & 0 & 5 & 0 & 6 & 0 & 4 & 0 & 81 \\
\hline 40 & 0 & 31 & 0 & 43 & 0 & 6 & 0 & 38 & 0 & 33 & 0 & 319 \\
\hline 0 & 0 & 0 & 0 & 0 & 0 & 0 & 0 & 0 & 0 & 0 & 0 & 129 \\
\hline
\end{tabular}


$( \pm 0.11) \mathrm{pg} / \mu \mathrm{l}$ of PMeV-Mx RNA from $20 \mathrm{ng} / \mu \mathrm{l}$ of cDNA. The viral titer of PMeV-Mx in E. papayae increased with time, reaching a maximum titer at 5 dae, with an estimated value of $2.125( \pm 0.19)$ $\mathrm{pg} / \mu \mathrm{l}$ of PMeV-Mx RNA from $20 \mathrm{ng} / \mu \mathrm{l}$ of cDNA (Fig. 2A). However, PMeV-Mx was not detected in E. papayae nymphs (Fig. 2B).

Once the transmission test was concluded, it could be proven that E. papayae transmitted the $\mathrm{PMeV}-\mathrm{Mx}$ in $100 \%$ of the plants evaluated under the conditions established in the present study.

PMeV-Mx was detected and quantified by RT-qPCR in the new leaves of all $C$. papaya plants from 14 days after insect liberation. The $C_{T}$ values decreased in later evaluations $(21,28,35$, and 60 dae), indicating an increase in the viral titer of the plants exposed to insects carrying $\mathrm{PMeV}-\mathrm{Mx} . \mathrm{C}_{\mathrm{T}}$ values were found within a range of 33 at 21 dae down to 26 at 35 and 60 dae. The quantification of PMeV-Mx RNA in new leaves of $C$. papaya revealed estimated values of $0.06 \mathrm{pg} / \mu \mathrm{l}$ at $21 \mathrm{dae}$ from $20 \mathrm{ng} / \mu \mathrm{l}$ of cDNA up to $25.8 \mathrm{pg} / \mu \mathrm{l}$ at 35 dae and $26.6 \mathrm{pg} / \mu \mathrm{l}$ at 60 dae, both from $20 \mathrm{ng} / \mu \mathrm{l}$ of cDNA (Fig.

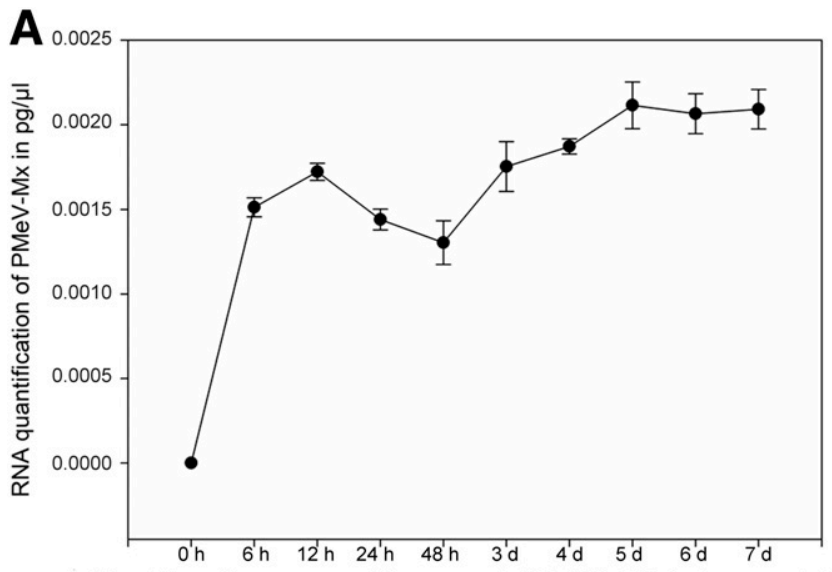

Hours/days after exposure of $E$. papayae to $\mathrm{PMeV}-\mathrm{Mx}$-infected papaya plants

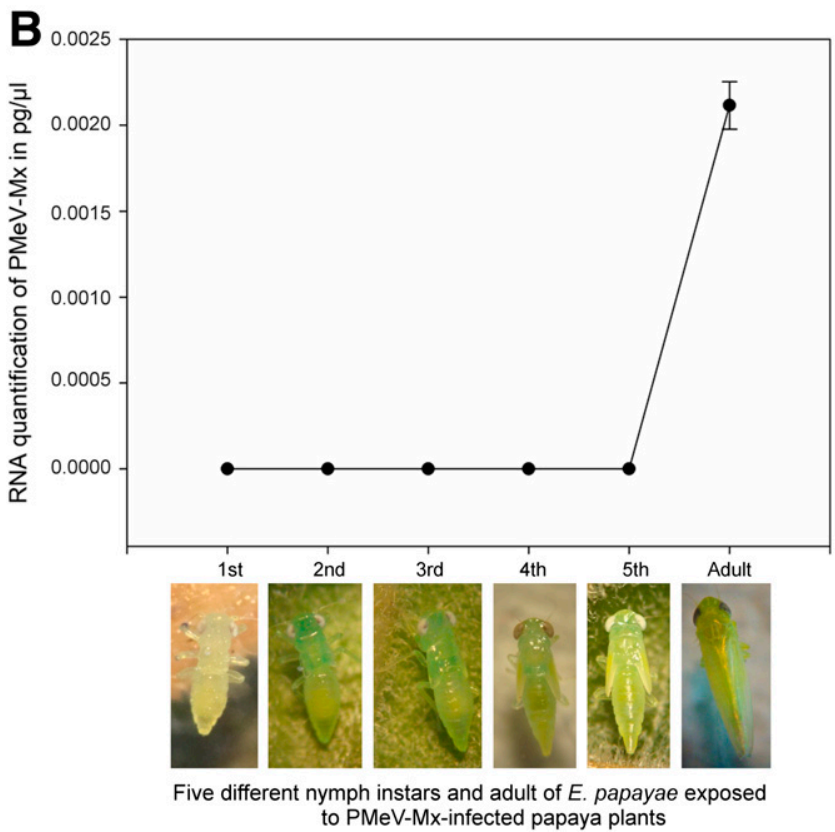

Fig. 2. Viral load of papaya meleira virus Mexican variant (PMeV-Mx) in Empoasca papayae exposed to infected papaya plants during a 7-day acquisition access period and in different life-cycle stages. A, TaqMan quantitative reverse transcription polymerase chain reaction (RT-qPCR) of PMeV-Mx in E. papayae adults exposed to PMeV-Mx-infected papaya plants $\left(R^{2}=0.999\right)$, from $0 \mathrm{~h}$ to 7 days after exposure. All data shown are mean values ( \pm standard error) in $\mathrm{pg} / \mu \mathrm{l}$ of the PMeV-Mx-RNA of three biological replicates. B, TaqMan RT-qPCR of $\mathrm{PMeV}-\mathrm{Mx}$ in different nymph instars and adult $E$. papayae exposed to PMeV-Mxinfected papaya plants $\left(R^{2}=0.999\right)$. All data shown are mean values $( \pm$ standard error) in $\mathrm{pg} / \mu \mathrm{l}$ of the PMeV-Mx-RNA of three biological replicates.
3A), demonstrating that E. papayae is capable of transmitting PMeVMx to papaya plants.

The sequencing of a fragment of each sample confirmed that the PCR products (491 bp) corresponded to the expected viral sequence, showing a $98 \%$ similarity with the RdRp gene of PMeV-Mx (KF214786.1). No symptoms of papaya sticky disease were observed in papaya plants used as negative controls. Likewise, they were negative to PMeV-Mx by RT-qPCR in all experiments. According to our results, E. papayae was the first identified vector involved in the transmission of PMeV-Mx and was capable of acquiring and transmitting this virus under our experimental conditions.

All papaya plants exposed to viruliferous E. papayae adults developed sticky disease symptoms within 3 to 4 months after insect exposure (Fig. 3B). These plants showed an exudation of translucent and watery latex and dark scabs on the diseased fruit surfaces, which was caused by oxidized latex. These were the most distinctive and typical symptoms produced by the $\mathrm{PMeV}$ infection.

\section{Discussion}

Sticky disease is among the most important diseases for papaya crops in Brazil and Mexico. One of the main problems with this disease is that the causal agent disperses rapidly, reaching an incidence of up to $100 \%$, when the sources of the inoculum are not eliminated from the field (Abreu et al. 2015; Ventura et al. 2004). Studies on the field spread pattern of this disease, carried out in Brazil and Mexico, reveal an infected plant distribution that suggests the participation of an aerial vector in PMeV transmission (Abreu et al. 2015; Gouvea et al. 2018; Rodrigues et al. 2009). In this work, we analyzed the diversity and abundance of insects present in experimental and commercial papaya orchards to find those predominant species that could be involved in the transmission of PMeV. The high diversity of insects found in papaya orchards includes at least 31 genera belonging to different orders, such as Amblypelta spp., Draeculacephala spp., E. papayae, Hortensia spp., Aphis spp., and Chrysoperla carnea, some of which have previously been reported in papaya fields in other countries (Acosta Pérez et al. 2010; Gouvea et al. 2018; Pantoja et al. 2002; Saengyot and Burikam 2011).

Among all the genera or species of insects collected in the five papaya orchards under study, those belonging to the leafhopper family (Hemiptera: Cicadellidae) were the most abundant. This is important in terms of plant virus transmission, because leafhoppers are vectors of at least 31 plant virus species (Ammar et al. 2007; Hogenhout et al. 2008; Nault 1997; Nault and Ammar 1989; Todd et al. 2010). In fact, the most economically important insect vectors are restricted to a few Hemiptera families, such as Aphididae (aphids) and Aleyrodidae (whiteflies) of the suborder Sternorrhyncha, Cicadellidae (leafhoppers) of the suborder Cicadomorpha, and Delphacidae (delphacid planthoppers) of the suborder Fulgoromorpha (Hogenhout et al. 2008). In a recent study, carried out in Brazil, it was observed that the number of papaya plants infected with $\mathrm{PMeV}$ increased, and at the same time there was a peak in the leafhopper population increase in this crop. The genera of Cicadellidae predominant in those $\mathrm{PMeV}$ infected orchards were Solanasca and Empoasca (Gouvea et al. 2018).

To our knowledge, there are no previous reports on the diversity and abundance of insects in papaya fields in Mexico, so this work contributes to new insights into insect species associated with papaya crops, which could be involved in the transmission of phytopathogens.

Interactions between plant viruses and insect vectors are very specific; in most cases, the same type of vector transmits viruses of a given taxon ( $\mathrm{Ng}$ and Falk 2006). For example, members of the genus Potyvirus are transmitted specifically and nonpersistently by aphids (Ng and Perry 2004), and begomoviruses are transmitted specifically and persistently by whitefly species, mainly B. tabaci (Power 2000). However, in the case of $\mathrm{PMeV}$, it is not possible to analyze taxonomic relationships that allow us to suggest that some aerial vector may be involved in its transmission, because the International Committee on the Taxonomy of Viruses has not classified PMeV (Abreu et al. 2015). In our study, we tested all species found in papaya 
orchards for PMeV-Mx presence by RT-qPCR. PMeV-Mx was detected in six leafhopper species or genera (D. soluta, A. novella, Xyphon spp., Hortensia spp., A. constricta, and E. papayae). PMeV-Mx was also detected in Aphis spp. However, this genus was found in high abundance only during the February sampling. Previously, Trialeurodes variabilis, a whitefly species in high abundance in Brazilian papaya fields and considered a pest to Brazilian papaya and other fruit trees, was unable to transmit $\mathrm{PMeV}$ from diseased to healthy papayas, even though the virus was present in adults and nymphs (Rodrigues et al. 2009). However, no whitefly species were found in the papaya orchards sampled in this study.

E. papayae (Hemiptera: Cicadellidae) was the most abundant leafhopper species found in the papaya fields included in this study. This species has been found in papaya plantations in Puerto Rico, Santo Domingo, Haiti, Jamaica, and Cuba, being the most abundant species of this crop (Martorell and Adsuar 1952).

E. papayae is able to produce damage by direct feeding, known as "hopperburn," characterized by tip wilting, leaf chlorosis, premature leaf drop, and plant stunting, usually caused by a reduction in stem elongation (Backus et al. 2005). However, this leafhopper is considered a limiting factor in the production of papaya owing to its vector capacity. E. papayae was reported as a simultaneous vector of the 16 SrI-B and 16SrII phytoplasmas and rickettsia associated with bunchy top symptoms (BTS) in Cuba, where high population densities of E. papayae were associated with an increasing incidence of BTS in the same papaya field (Acosta et al. 2017; Acosta Pérez et al. 2010). One study reported E. papayae as the vector of papaya apical necrosis virus. In that study, papaya plants showed symptoms after being exposed to viruliferous E. papayae adults. However, rhabdovirus particles were not found in tissues that showed symptoms of the disease (Lastra and Quintero 1981).

The transmission efficiency of plant viruses transmitted by leafhoppers is not always high. For maize streak virus transmitted by Cicadulina mbila, the efficiency ranged between 40 and $45 \%$ (Bosque-Pérez and Buddenhagen 1999), and in another study it reached up to $90 \%$ (Reynaud and Peterschmitt 1992). Meanwhile, for maize rayado fino virus, transmitted by Dalbulus maidis, the transmission efficiency was 70\% (Nault et al. 1980). There are some reports of transmission efficiencies as high as $100 \%$. For example, in an experiment using 10 Circulifer tenellus leafhoppers per plant, the transmission efficiency of beet curly top virus to sugar beet was $100 \%$ (Wang et al. 1999). In another study, the leafhopper vector, Psammotettix alienus, transmitted wheat dwarf virus to wheat and barley hosts with a $100 \%$ infection rate (Parizipour et al. 2016).

The quantification of PMeV in E. papayae by RT-qPCR showed that this leafhopper is able to acquire the virus within $6 \mathrm{~h}$ after exposure to PMeV-infected plants. Acquisition threshold times in leafhopper vectors are very different and vary from a few seconds to several hours. For example, the field vector, Graminella nigrifrons, can acquire maize chlorotic dwarf virus from infected plants or inoculate healthy plants in $15 \mathrm{~min}$, whereas Nephotettix virescens requires $30 \mathrm{~min}$ to acquire or inoculate rice tungro bacilliform virus. On the other hand, vectors such as Graminella sonora, Laodelphax striatellus, and Recilia dorsalis required 6, 5, and $8 \mathrm{~h}$, respectively, for sorghum stunt mosaic rhabdovirus (Creamer et al. 1997), barley yellow striate mosaic virus (Conti 1980), and rice gall dwarf virus acquisition (Morinaka et al.1982). However, longer AAPs and IAPs increase transmission efficiency, because for circulative and propagative viruses longer latent periods are needed before leafhoppers can become inoculative, because the ingested virus needs to be incorporated into salivary secretions (Nault and Ammar 1989).

In this study, the viral titer in E. papayae increased from $6 \mathrm{~h}$ to 5 days. After exposure to PMeV-infected plants, it was maintained, and it when the transmission experiment was initiated, under these conditions, transmission was $100 \%$ successful.

A low efficiency of transmission has been demonstrated in other leafhopper species during the first days after the acquisition of the virus, which increases up to $90 \%$ from 10 to 17 days after the acquisition (Reynaud and Peterschmitt 1992). This may be owing to the rapid circulation of the viral particles through the filter chamber within the vector's body (a few minutes after AAP) and to the long retention period of the virions within the leafhopper vector (Wang et al. 2014). Similar studies are required to clarify the interactions between $\mathrm{PMeV}-\mathrm{Mx}$ and E. papayae. In addition, it is necessary to
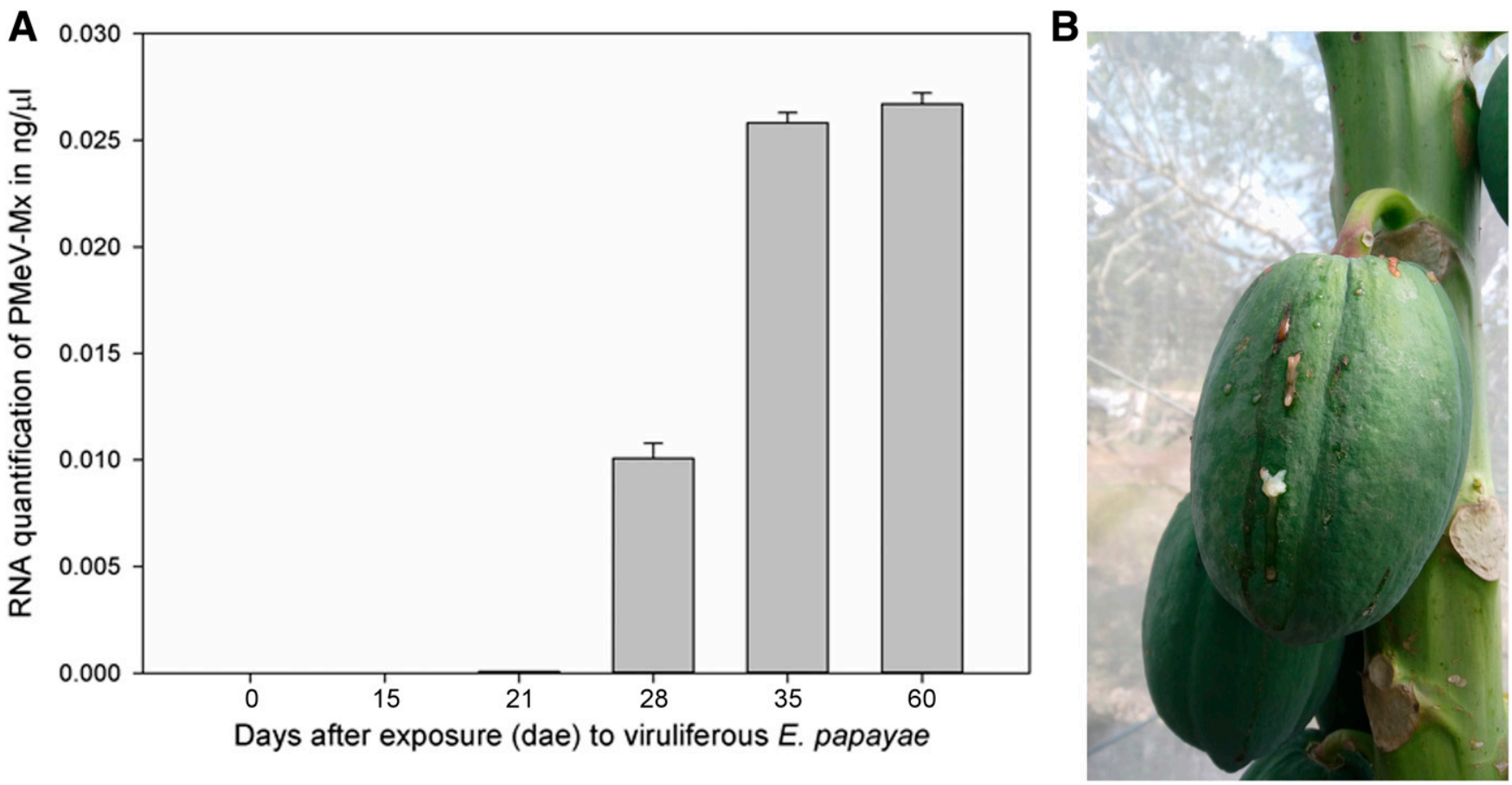

Fig. 3. Viral load and symptoms in papaya plants infected with papaya meleira virus Mexican variant (PMeV-Mx) by Empoasca papayae. A, TaqMan quantitative reverse transcription polymerase chain reaction of PMeV-Mx in Carica papaya 'Maradol' plants $\left(R^{2}=0.999\right)$ exposed to viruliferous $E$. papayae adults. All data shown are mean values ( \pm standard error) in $\mathrm{pg} / \mu \mathrm{l}$ of the PMeV-Mx-RNA of three biological replicates. B, Sticky disease symptoms in papaya plants exposed to viruliferous $E$. papayae. All these papaya plants show an exudation of translucent and watery latex within 3 to 4 months after insect exposure. 
evaluate shorter AAPs and retention of the virus in the vector's body to determine the possible type of transmission.

The vector life stage is an important factor in the transmission of many insect-borne plant viruses, and usually, transmission efficiency is higher when vectors acquire a virus as nymphs rather than as adults, with nymphs being generally more susceptible to virus acquisition than adults (Todd et al. 2010). For example, G. nigrifrons nymphs acquire maize fine streak virus at higher titers than do adults, although the differences in titer do not translate directly into differences in inoculativity (Todd et al. 2010). In contrast, Recilia dorsalis nymphs have higher rice stripe mosaic virus acquisition and inoculation rates than do adults (Yang et al. 2017). However, PMeV-Mx was not detected in any of the different instar stages of E. papayae, showing that $E$. papayae nymphs are probably not capable of acquiring this virus.

The epidemiology of vector-borne plant viruses is directly dependent on the biology of the vector species, including the host range and feeding preferences (Cvrković et al. 2014; Pu et al. 2012). Unfortunately, the biology, host plant associations, and feeding preferences of E. papayae are not well documented. To date, all findings suggest that this leafhopper is a monophagous species that, until now, has not been reported in any species other than C. papaya. In fact, E. papayae is commonly known as the "papaya leafhopper" because it is the leafhopper's only known host (Nielson 1968).

In contrast, other species of the Empoasca genus have different plant associations. For example, E. decipiens is extremely polyphagous and has been reported in different crops, being a pest for beans, potatoes, cotton, and sesame (Galetto et al. 2011). In the case of $E$. fabae, this vector has been recognized as an important pest in many crops in the United States, being able to reproduce on more than 200 plant species belonging to 25 families (Shields and Testa 1999). Therefore, there is still much left to study regarding the biology of E. papayae.

The epidemiology of plant viruses is multifaceted and very diverse, involving a tripartite pathosystem in which each component (virus, vector, and host) interacts with the environment (Jones 2014). Different environmental parameters determine the behavior of viruses and their vectors and, consequently, the transmission efficiency and the rapid dispersion and incidence of viral diseases in the field (Gingery et al. 2004; Jones 2014). Studies on the biology of $E$. papayae are required. Knowing the population dynamics of the vector species, the propagation pattern of the virus, the vector host range, the mode of transmission of the virus, and whether the vector is colonizing permits the implementation of phytosanitary management strategies.

The present study demonstrated the ability of E. papayae Oman (Hemiptera: Cicadellidae) to acquire and transmit PMeV-Mx to $C$. papaya 'Maradol'. Transmission tests reveal a high rate of the transmission of this virus by adult insects of this vector to healthy papaya plants under established experimental conditions. PMeV-Mx was detected and quantified in all papaya plants exposed to E. papayae adults, which carried this virus from 21 dae, to diseased plants. This is the first report of PMeV-Mx transmission by an aerial vector. Increasing our knowledge about the cycle and epidemiology of sticky disease will be useful for the development of disease control strategies.

\section{Acknowledgments}

The authors thank Héctor Enrique Vega Ortiz (Head of Entomology and Acarology Department, National Phytosanitary Reference Center, SENASICA, Mexico) for the morphological identification of all insects studied in this work. Acknowledgments also go to Máximo Paredes Rodríguez (Head of Rural Development and Commercialization Department) of Rural Development Secretariat of Yucatan (SEDER), for the support for insect samplings in papaya orchards. In addition, the authors thank Fernando Amilcar Contreras (Yucatan Center for Scientific Research, CICY) for his technical assistance in maintenance in greenhouse of papaya plants used in this study.

\section{Literature Cited}

Abreu, P. M. V., Antunes, T. F. S., Magaña-Álvarez, A., Pérez-Brito, D., TapiaTussell, R., Ventura, J. A., Fernandes, A. A. R., and Fernandes, P. M. B. 2015. A current overview of the papaya meleira virus, an unusual plant virus. Viruses 7:1853-1870.
Abreu, P. M. V., Piccin, J. G., Rodrigues, S. P., Buss, D. S., Ventura, J. A., and Fernandes, P. M. 2012. Molecular diagnosis of papaya meleira virus (PMeV) from leaf samples of Carica papaya L. using conventional and real-time RTPCR. J. Virol. Methods 180:11-17.

Acosta, K. I., Zamora, L., Piñol, B., Quiñones, M. L., Ramos, P. L., Luis, M., Leyva-Lopez, N. E., and Arocha, Y. 2017. Empoasca papayae Oman, 1937 (Hemiptera: Cicadellidae) the simultaneous vector of phytoplasmas and rickettsia associated with "bunchy top symptom" in Cuba. An. Biol. 39:35-42.

Acosta Pérez, K., Piñol, B., Arocha, Y., Wilson, M., Boa, E., and Lucas, J. 2010. Transmission of the phytoplasma associated with bunchy top symptom of papaya by Empoasca papayae Oman. J. Phytopathol. 158:194-196.

Ammar, E. D., Khlifa, E. A., Mahmoud, A., Abol-Ela, S. E., and Peterschmitt, M 2007. Evidence for multiplication of the leafhopper-borne maize yellow stripe virus in its vector using ELISA and dot-blot hybridization. Arch. Virol. 152: 489-494.

Backus, E., Serrano, M., and Ranger, C. 2005. Mechanisms of hopperburn: An overview of insect taxonomy, behavior, and physiology. Annu. Rev. Entomol. 50:125-151.

Bosco, D., and Tedeschi, R. 2013. Insect vector transmission assays. Pages 73-85 in: Phytoplasma: Methods and Protocols. M. Dickinson and J. Hodgetts, eds. Humana Press, Totowa, NJ.

Bosque-Pérez, N. A., and Buddenhagen, I. W. 1999. Biology of Cicadulina leafhoppers and epidemiology of maize streak virus disease in West Africa. S. Afr. J. Plant Soil 16:50-55.

Conti, M. 1980. Vector relationships and other characteristics of barley yellow striate mosaic virus (BYSMV). Ann. Appl. Biol. 95:83-92.

Creamer, R., He, X., and Styer, W. E. 1997. Transmission of sorghum stunt mosaic rhabdovirus by the leafhopper vector, Graminella sonora (Homoptera: Cicadellidae). Plant Dis. 81:63-65.

Cvrković, T., Jović, J., Mitrović, M., Krstić, O., and Toševski, I. 2014. Experimental and molecular evidence of Reptalus panzeri as a natural vector of bois noir. Plant Pathol. 63:42-53.

Doyle, J. J., and Doyle, J. L. 1987. A rapid DNA isolation procedure for small quantities of fresh leaf tissue. Phytochem. Bull. 19:11-15.

FAOSTAT. 2018. Statistical databases. Food and Agricultural Organization of the United Nations, Rome, Italy.

Folmer, O., Black, W., Hoeh, R., and Vrijenhoek, R. 1994. DNA primers for amplification of mitochondrial cytochrome c oxidase subunit I from diverse metazoan invertebrates. Mol. Mar. Biol. Biotechnol. 3:294-299.

Galetto, L., Bosco, D., Balestrini, R., Genre, A., Fletcher, J., and Marzachi, C. 2011. The major antigenic membrane protein of 'Candidatus Phytoplasma asteris' selectively interacts with ATP synthase and actin of leafhopper vectors. PLoS One 6:e22571.

Galetto, L., Bosco, D., and Marzachi, C. 2013. Selection of reference genes from two leafhopper species challenged by phytoplasma infection, for gene expression studies by RT-qPCR. BMC Res. Notes 6:409.

García-Cámara, I., Pérez-Brito, D., Moreno-Valenzuela, O., Magaña-Álvarez, A., Fernandes, P. M. B., and Tapia-Tussell, R. 2018. Molecular and experimental evidence of watermelon (Citrullus lanatus) as host of the Mexican variant of papaya meleira virus. Eur. J. Plant Pathol. 151:117-123.

Gingery, R. E., Anderson, R. J., and Redinbaugh, M. G. 2004. Effect of environmental conditions and leafhopper gender on maize chlorotic dwarf virus transmission by Graminella nigrifrons (Homoptera: Cicadellidae). J. Econ. Entomol. 97:768-773.

Gouvea, R. R., da Vitória, R. Z., Rosa, R., Alves, W. D. S., Giuriatto, N., Calatroni, D., Fanton, C., Martins, D. S., and Queiroz, R. B. 2018. Flutuação populacional de cigarrinhas (Hemiptera: cicadellidae) e ocorrência do vírus da meleira do mamoeiro. VII Simpósio do Papaya Brasileiro. Produção e Sustentabilidade Hídrica. Vitória-Espirito Santo, Brazil, 22-25 August, 2018.

Hogenhout, S. A., Ammar, E. D., Whitfield, A. E., and Redinbaugh, M. G. 2008 Insect vector interactions with persistently transmitted viruses. Annu. Rev. Phytopathol. 46:327-359.

Jones, R. A. C. 2014. Trends in plant virus epidemiology: Opportunities from new or improved technologies. Virus Res. 186:3-19.

Kuang, J., Yan, X., Genders, A. J., Granata, C., and Bishop, D. J. 2018. An overview of technical considerations when using quantitative real-time PCR analysis of gene expression in human exercise research. PLoS One 13: e0196438.

Lastra, R., and Quintero, E. 1981. Papaya apical necrosis, a new disease associated with a rhabdovirus. Plant Dis. 65:439-440.

Maciel-Zambolim, E., Kunieda-Alonso, S., Matsuoka, K., De Carvalho, M. G., and Zerbini, F. M. 2003. Purification and some properties of papaya meleira virus, a novel virus infecting papayas in Brazil. Plant Pathol. 52:389-394.

Martorell, L. F., and Adsuar, J. 1952. Insects associated with papaya virus diseases in the Antilles and Florida. J. Agric. Univ. P. R. 36:319-329.

Morinaka, T., Putta, M., Chettanachit, D., Parejarearn, A., Disthaporn, S., Omura, T., and Inoue, H. 1982. Transmission of rice gall dwarf virus by cicadellid leafhoppers Recilia dorsalis and Nephotettix nigropictus in Thailand. Plant Dis. 66:703-704.

Nault, L. R. 1997. Arthropod transmission of plant viruses: A new synthesis. Ann. Entomol. Soc. Am. 90:521-541.

Nault, L. R., and Ammar, E. D. 1989. Leafhopper and planthopper transmission of plant-viruses. Annu. Rev. Entomol. 34:503-529. 
Nault, L. R., Gingery, R. E., and Gordon, D. T. 1980. Leafhopper transmission and host range of maize rayado fino virus. Phytopathology 70:709-712.

Ng, J. C. K., and Falk, B. W. 2006. Virus-vector interactions mediating nonpersistent and semipersistent transmission of plant viruses. Annu. Rev. Phytopathol. 44:183-212.

Ng, J. C. K., and Perry, K. L. 2004. Transmission of plant viruses by aphid vectors. Mol. Plant Pathol. 5:505-511.

Nielson, M. W. 1968. The leafhopper vectors of phytopathogenic viruses (Homoptera: Cicadellidae) taxonomy, biology and virus transmission. Tech. Bull. No. 1382, Pages 146-146. Agric. Res. Serv., U.S. Department of Agriculture.

Pantoja, A., Follet, P., and Villanueva, J. A. 2002. Pests of papaya. Pages 131-156 in: Tropical Fruit Pests and Pollinators: Biology, Economic Importance, Natural Enemies, and Control. J. Peña, J. Sharp, and M. Wysoki, eds. CAB International, Wallingford, U.K.

Parizipour, M. G., Behjatnia, S. A. A., Afsharifar, A., and Izadpanah, K. 2016. Natural hosts and efficiency of leafhopper vector in transmission of wheat dwarf virus. J. Plant Pathol. 98:483-492.

Pérez-Brito, D., Tapia-Tussell, R., Cortes-Velazquez, A., Quijano-Ramayo, A., Nexticapan-Garcez, A., and Martín-Mex, R. 2012. First report of papaya meleira virus (PMeV) in Mexico. Afr. J. Biotechnol. 11:13564-13570.

Power, A. G. 2000. Insect transmission of plant viruses: A constraint on virus variability. Curr. Opin. Plant Biol. 3:336-340.

Pu, L., Xie, G., Ji, C., Ling, B., Zhang, M., Xu, D., and Zhou, G. 2012. Transmission characteristics of Southern rice black-streaked dwarf virus by rice planthoppers. Crop Prot. 41:71-76.

Quito-Avila, D. F., Alvarez, R. A., Ibarra, M. A., and Martin, R. R. 2015. Detection and partial genome sequence of a new umbra-like virus of papaya discovered in Ecuador. Eur. J. Plant Pathol. 143:199-204.

Reynaud, B., and Peterschmitt, M. 1992. A study of the mode of transmission of maize streak virus by Cicadulina mbila using an enzyme-linked immunosorbent assay. Ann. Appl. Biol. 121:85-94.

Rodrigues, C. H., Alves, F. L., and Marin, S. L. D. 1989. Ocorrencia e sintomas de meleira do mamoeiro (Carica papaya) no estado do Espiritu Santo. Fitopatol. Bras. 14:108.

Rodrigues, S. P., Andrade, J. S., Ventura, J. A., Lindsey, G. G., and Fernandes, P. M. B. 2009. Papaya meleira virus is neither transmitted by infection at wound sites nor by the whitefly Trialeurodes variabilis. J. Plant Pathol. 1:87-91.

Sá Antunes, T. F., Amaral, R. J. V., Ventura, J. A., Godinho, M. T., Amaral, J. G., Souza, F. O., Zerbini, P. A., Zerbini, F. M., and Fernandes, P. M. B. 2016. The dsRNA virus papaya meleira virus and an ssRNA virus are associated with papaya sticky disease. PLoS One 11:e0155240.

Saengyot, S., and Burikam, I. 2011. Host plants and natural enemies of papaya mealybug, Paracoccus marginatus (Hemiptera: Pseudococcidae) in Thailand. Thai J. Agric. Sci. 44:197-205.

Secretaría de Agricultura, Ganadería, Desarrollo Rural, Pesca y Alimentación (SAGARPA). 2017. Amplificación de la región mtADN CO-I, para la identificación de insectos por PCR punto final. Area de desarrollo y validación de protocolos, Sanidad Vegetal, México.

Shields, E. J., and Testa, A. M. 1999. Fall migratory flight initiation of the potato leafhopper, Empoasca fabae (Homoptera: Cicadellidae): Observations in the lower atmosphere using remote piloted vehicles. Agric. For. Meteorol. 97:317-330.

Sieburth, P. J., Nolan, K. G., Alderman, S. M., and Dexter, R. J. 2009. Increased efficiency and sensitivity for identifying citrus greening and citrus tristeza virus using real-time PCR testing. Proc. Fla. State Hortic. Soc. 122:141-146.

Stansly, P. A., Arevalo, H. A., Qureshi, J. A., Jones, M. M., Hendricks, K., Roberts, P. D., and Roka, F. M. 2014. Vector control and foliar nutrition to maintain economic sustainability of bearing citrus in Florida groves affected by huanglongbing. Pest Manag. Sci. 70:415-426.

Tapia-Tussell, R., Magaña-Alvarez, A., Cortez-Velazquez, A., Itza-Kuk, G., Nexticapan-Garcez, A., Quijano-Ramayo, A., Martin-Mex, R., and PerezBrito, D. 2015. Seed transmission of papaya meleira virus in papaya (Carica papaya) cv. Maradol. Plant Pathol. 64:272-275.

Tapia-Tussell, R., Suaste-Dzul, A., Cortes-Velazquez, A., Torres-Calzada, C. Quijano-Ramayo, A., Martin-Mex, R., Nesticapan-Garcez, A., and PerezBrito, D. 2012. Molecular characterization of Yucatan tomato phytoplasma (group 16Sr III). Afr. J. Biotechnol. 11:2169-2177.

Tavares, E. T., Tatagiba, J. S., Ventura, J. A., and Souza, M. T., Jr. 2004. Two new systems of early diagnosis of papaya sticky disease. Fitopatol. Bras. 29: 563-566.

Todd, J. C., Ammar, E. D., Redinbaugh, M. G., Hoy, C., and Hogenhout, S. A 2010. Plant host range and leafhopper transmission of maize fine streak virus. Phytopathology 100:1138-1145.

Ventura, J. A., Costa, H., and Tatagiba, J. S. 2004. Papaya diseases and integrated control. Pages 201-268 in: Diseases of Fruits and Vegetables: Diagnosis and Management S. A. M. H. Naqvi, ed. Klumer Academic Publishers, the Netherlands.

Vidal, C. A., Nascimento, A. S., and Habibe, T. C. 2003. Transmissão do vírus da meleira do mamoeiro por insetos. Pages 612-615 in: Papaya Brasil: Qualidade do Mamão Para o Mercado Interno. D. S. Martin, ed. Incaper, Vitória, Brazil.

Wang, H., Gurusinghe, P. A., and Falk, B. W. 1999. Systemic insecticides an plant age affect beet curly top virus transmission to selected host plants. Plant Dis. 83:351-355

Wang, Y., Mao, Q., Liu, W., Mar, T., Wei, T., Liu, Y., and Wang, X. 2014 Localization and distribution of wheat dwarf virus in its vector leafhopper, Psammotettix alienus. Phytopathology 104:897-904.

Yang, X., Zhang, T., Chen, B., and Zhou, G. 2017. Transmission biology of rice stripe mosaic virus by an efficient insect vector Recilia dorsalis (Hemiptera: Cicadellidae). Front. Microbiol. 8:2457.

Zamudio-Moreno, E., Ramírez-Prado, J. H., Moreno-Valenzuela, O. A., and López-Ochoa, L. A. 2015. Early diagnosis of a Mexican variant of papaya meleira virus (PMeV-Mx) by RT-PCR. Genet. Mol. Res. 14:1145-1154. 